\title{
Physicochemical properties and sensory attributes of herbal pastilles affected by the inclusion of Clitoria ternatea (L.) leaves
}

\author{
${ }^{1}$ Ramlan, N.N.F., ${ }^{1}$ Mohd Zin, Z., ${ }^{2}$ Juhari, N.H., ${ }^{3}$ Smedley, K.L. and ${ }^{1, * Z a i n o l, ~ M . K . ~}$ \\ ${ }^{1}$ Faculty of Fisheries and Food Science, Universiti Malaysia Terengganu, 21030, Kuala Nerus, Terengganu \\ ${ }^{2}$ Faculty of Food Science and Technology, Universiti Putra Malaysia, 43400, Serdang, Selangor, Malaysia \\ ${ }^{3}$ Strafford School, Stratford-upon-Avon, Warwickshire, CV37 9DH, United Kingdom
}

Article history:

Received: 24 August 2020

Received in revised form: 22 September 2020

Accepted: 17 November 2020

Available Online: 13

February 2021

\section{Keywords:}

Antioxidative activities,

Clitoria ternatea,

Sensory analysis,

Pastille

DOI:

https://doi.org/10.26656/fr.2017.5(1).463

\begin{abstract}
Clitoria ternatea (L.) (Bunga Telang), is a well-known plant used as food colouring through its flowers. The plant's leaves are also being used as medicinal ingredients to cure several diseases. However, the medicinal properties were not being explored extensively which could diversify the plant's usage. The research was conducted on the inclusion of C. ternatea leaves to enhance the physicochemical properties and sensory acceptability of herbal pastille. Five different formulations of $C$. ternatea leaves pastille were developed with different percentages of $C$. ternatea leaves namely $2.5 \%, 5.0 \%, 7.5 \%, 10.0 \%$ and 12.5\%. Physicochemical properties (antioxidant properties, colour profile, texture, moisture, sugar, fat, protein, ash, calorie and texture profile) and the sensory acceptability of $C$. ternatea leaves pastille was observed. The results show that the highest ${ }^{\circ}$ Brix value was observed in sample D $\left(74.20^{\circ}\right)$ while water activity was higher in sample B (0.73). The analysis showed that the control sample exhibited a high hardness value $(2641.70 \mathrm{~N})$, springiness and cohesion values $(0.87 \mathrm{~N})$, gumminess value $(2338.75 \mathrm{~N})$, chewiness value $(2089.71 \mathrm{~N})$ and resilience value $(0.44 \mathrm{~N})$ to that of $C$. ternatea leaves herbal pastille. Sample E was found to contain a high TFA value (1.45), TPC value (23.32 GAE mg/g), and DPPH value (27.72\%). Based on overall acceptance, the sensory analysis showed that the products were accepted by the panellists. Thus, the study revealed that the physicochemical properties of developed herbal pastille were being enhanced and found to be rich in antioxidants and accepted by the panellists.
\end{abstract}

\section{Introduction}

C. ternatea or butterfly pea is well known for its colouring properties rather than its medicinal uses (Lijon et al., 2017). It belongs to the Fabaceae family and is commonly known as Bunga Biru, Kacang Telang, Kacang Puki (Malaysia), Mentelang (Java), Ang Chan (Thailand), and Bikol (Philippines) (Lim, 2014). C. ternatea's flower, fruit and leaves are edible (Kaisoon et al., 2001; Wetwitayaklung et al., 2008) while the flowers and leaves are usually used as natural food colouring agents in cooking in Southeast Asia. In addition, the root, leaves and flowers are used in the form of powder and decoction to cure diseases (Neda et al., 2013). The plant's leaves are also used to treat wounds, food colouring (Lim, 2014) and as a brain tonic as they are believed to enhance memory and intelligence (Mukherjee et al., 2008). Moreover, there are not many products derived from these leaves and normally only directly used to cure disease such as diabetes, oedema, mental disorder, goitre, vitiligo, snake poisoning, toothache, eye disease, fever, asthma and jaundice by using its root, leaves or flowers in form of powder and decoction (DeFilipps and Krupnick, 2018). C. ternatea leaves were chosen as the main ingredient in this study to highlight its use in medicinal fields besides being used as blue colouring in food (Lim, 2014).

Pastilles are soft candy but softer than gums yet not as soft as jellies, which has a rubber impact by using part of the gum and gelatine (Zainol et al., 2020). They were made for medication to relieve sore throats, cough and oral thrush as active pharmaceutical products were unpleasant to be consumed in the eighteenth century (Lubbers and Guichard, 2003). However, creative development has commercialized the pastille and it is often associated with fruit and sweet products and loved by children (Shukri et al., 2017). The advantages of 
pastille products are their long shelf life, less prone to microbial spoilage due to the sugar content (Subramaniam, 2011).

The development of pastilles containing the leaves of $C$. ternatea might change the perception of consumers towards herb products in form of confectionery, especially children. This research aimed to produce healthier candy-like products containing herbs instead of high sugar, artificial colour and flavour and other food additives that could have long-term adverse effects on their body. $C$. ternatea was chosen as the main ingredient of the pastille as an alternative way to consume herbs instead of directly using them after basic heat treatment such as boiling and sun drying. Consequently, the development of $C$. ternatea's leaf pastille gives variety to the natural products on the market and also the additional nutritional benefits to the consumer without losing the physical properties of the pastille which is gummy in texture. Apart from variety, it is developed for its beneficial antioxidant properties. Therefore, the objective of this study was to determine the physicochemical as well as the sensory acceptability of the C. ternatea leaf.

\section{Materials and method}

\subsection{Production of pastille}

C. ternatea leaves were sorted, washed and chopped into slices and put over the water bath and steamed at low temperature for $3 \mathrm{mins}$ at $60 \mathrm{rpm}$. They were then cooled with ice-cold water to ensure enzyme inactivation prior to puree production. The leaves were crushed, ground and filtered using a muslin cloth (Zainol et al., 2020). In the various formulations of the pastilles, the amount of C. ternatea puree used was varied. (Table 1). A solution of sorbitol, glucose syrup and Arabic gum was mixed in a pot, cooked and permitted to cool at $75^{\circ} \mathrm{C}$. Arabic gum solution $\left(25^{\circ} \mathrm{C}\right)$ was then added and blended into the solution of sorbitol-glucose syrup. Gelatine and maize flour was then added when the temperature of the mixture reached $70^{\circ} \mathrm{C}$. The puree was added to the mixture at the last stage of cooking (50$55^{\circ} \mathrm{C}$ ). The cooked mixture was cooled to room temperature and citric acid was added to bring the $\mathrm{pH}$ of the mixture down to 3.5. Finally, the mixture was placed in the starch mould and stove in the dehydrator at $46^{\circ} \mathrm{C}$ for $16 \mathrm{hrs}$. To form fruit pastilles, the finished product was covered with fine sugar.

\subsection{Dimensions}

The thickness of pastille was determined by measuring the height of pastille samples placed edge to edge with a digital vernier calliper. The average value for thickness was reported in centimetres $(\mathrm{cm})$. The diameter of pastilles was determined by pastilles samples edge to edge and measured with a digital vernier calliper. An average of three values was taken for each set of samples. The average value for diameter was reported in centimetres $(\mathrm{cm})$. The weight of pastilles was measured as average values of six individual pastilles with the help of an analytical weighing balance (Azuan et al., 2020).

\subsection{Chemical analysis}

The proximate analysis was carried out to measure the value of moisture, ash, and crude fibre based on the Association of Official Analytical Chemist's procedure (AOAC, 2007).

\subsection{Calorie content}

Samples were dried overnight in the oven to remove all the moisture presents in the pastilles. Standards were measured before the samples to calibrate the bomb calorimeter. Approximately, $1 \mathrm{~g}$ of sample was then weighed after the drying and put in the specific pan. Precisely $2 \mathrm{~L}$ water was filled in the bucket inside the bomb bucket calorimeter's well. Ten centimetres of wire was placed in the slot. The bomb calorimeter was closed and the oxygen was pump into the system to allow the combustion. The bomb was inserted into the bucket, the system was set and the machine was started. After the pre-fire, fire and post-fire session, the wire left was measured as the calorie content (Azuan et al., 2020).

\subsection{Total phenolic content (TPC)}

Approximately $1 \mathrm{mg}$ of sample was added into 4.5 $\mathrm{mL}$ deionized water and $0.5 \mathrm{~mL}$ of Folin-Ciocalteu

Table 1. The ingredients in C. ternatea leaves pastille samples

\begin{tabular}{lcccccc}
\hline Ingredients & Control (\%) & Sample A (\%) & Sample B (\%) & Sample C (\%) & Sample D (\%) & Sample E (\%) \\
\hline C. ternatea's leaves & 0 & 2.5 & 5 & 7.5 & 10 & 12.5 \\
Water & 21.5 & 19 & 16.5 & 14 & 11.5 & 9 \\
Gelatine & & \multicolumn{2}{c}{7.5} & & \\
Sorbitol & & 20 & & \\
Glucose syrup & & 32.5 & & \\
Arabic Gum & & 15 & & \\
Citric Acid & & \multicolumn{2}{c}{1.5} & & \\
Corn Flour & & 2 & & & \\
\hline
\end{tabular}


phenol reagent. The mixture was allowed to stand for 5 min. After 5 mins, $1.5 \mathrm{~mL}$ of $20 \%(\mathrm{~m} / \mathrm{v})$ sodium carbonate was added and the volume was made up to 10 $\mathrm{mL}$ with distilled water. The samples were then incubated for $2 \mathrm{hrs}$ at room temperature. After incubation, absorbance was measured at $750 \mathrm{~nm}$ using a UV-visible spectrophotometer (SHIMADZU, Kyoto, Japan). The results were expressed as $\mathrm{mg}$ of gallic acid equivalent weight (GAE)/g sample (Hui et al., 2018).

\subsection{Total flavonoid content (TFC)}

An aliquot of the sample $(0.5 \mathrm{~mL})$ was added to a 10 $\mathrm{mL}$ volumetric flask containing $4 \mathrm{~mL}$ of distilled water. $0.3 \mathrm{~mL}$ of $5 \% \mathrm{NaNO}_{2}$ was then added. After 5 mins, 0.3 $\mathrm{mL}$ of $10 \% \mathrm{AlCl}_{3}$ was then added. After 5 mins, $2 \mathrm{~mL}$ of $1 \mathrm{M} \mathrm{NaOH}$ was added to the mix. The mixture volume was made up to $10 \mathrm{~mL}$ of distilled water. The solution was then mixed and the absorbance was measured at 510 nm (SHIMADZU, Kyoto, Japan). The total flavonoid contents were expressed as $\mathrm{mg}$ quercetin equivalents (QE) (Zainol et al., 2020).

\subsection{Antioxidant activity using 2, 2-diphenyl-2- picrylydrazyl (DPPH) analysis}

Briefly, $0.1 \mathrm{mM}$ solution of DPPH in methanol was prepared by dissolving $1.9 \mathrm{mg}$ DPPH in $100 \mathrm{~mL}$ methanol and incubated in the dark to complete the reaction. An aliquot of $4 \mathrm{~mL}$ of this solution was added to $10 \mathrm{~mL}$ of diluted extracts $(50 \mathrm{mg}$ sample in $100 \mathrm{~mL}$ distilled water), $10 \mathrm{~mL}$ of distilled water (control) and 10 $\mathrm{mL}$ of standard ascorbic acid, $\alpha$-tocopherol and Butylated hydroxyl toluene (BHT). The mixture was then left to incubate in the dark at room temperature for 60 mins. The absorbance was then measured at $517 \mathrm{~nm}$ using UV-Vis spectrophotometer (Malik et al. 2017).

\subsection{Physical analysis}

\section{$2.8 .1 \mathrm{pH}$}

To measure the $\mathrm{pH}$ of the product, buffer solutions of $\mathrm{pH} 7$ and $\mathrm{pH} 4$ were used to calibrate the $\mathrm{pH}$ meter and the sample was placed in a beaker with a sufficient amount to cover the tip. The $\mathrm{pH}$ was measured and the electrode was removed from the sample.

\subsubsection{Colour analysis}

The colour of the pastille was being measured using the Minolta colorimeter (Konica Minolta CR300, Japan). A white tile has been used for the calibration step. The pastille was tested and a reading taken. The pastilles must be covered the probe to get the most accurate reading and repeated three times to get the average value of $\mathrm{L}^{*} \mathrm{a}^{*}$ and $\mathrm{b}^{*}$ (Liew et al., 2020).

\subsubsection{Water activity}

Approximately, $2 \mathrm{~g}$ of the sample were ground into small pieces and put into a disposable cup and placed in the sample compartment of the water activity meter and analysed. An infrared beam focused in a tiny mirror determined the dew point and then the data was extracted the water activity value was recorded (Zhang et al., 2015).

\subsubsection{Texture analysis}

The instrumental texture measurements were made with a TA.XT.Plus texture analyser (Stable Microsystems, UK). A force-time graph was produced and textural parameters such as hardness, adhesiveness, springiness, cohesiveness, gumminess, chewiness and resilience were acquired with the assistance of the software supplied with the instrument (Azuan et al., 2020)

\subsubsection{Syneresis}

The pastille samples $(0.6 \mathrm{~g})$ and $9.6 \mathrm{~g}$ distilled water were boiled for 20 mins in test tubes. They were then cooled at room temperature and transferred into a centrifuge tube. The samples were then frozen at $-18^{\circ} \mathrm{C}$ for $24 \mathrm{hrs}$. The samples were then thawed and centrifuged at $4000 \mathrm{rpm}$ for 15 mins. The percentage of syneresis that took place in the pastilles produced from C. ternatea leaves was then calculated with (Zeng et al., 2014).

$\frac{\text { weight of water discarded }}{\text { weight of sample }} \times 100$

\subsection{Sensory evaluation and analysis}

Sensory evaluation is a scientific discipline used to evoke, measure, analyse and interpret those responses to products that are perceived by the sense of sight, smell, touch and hearing. The pastille samples were subjected to sensory evaluation for appearance, colour, odour, texture, taste and overall acceptance. The sensory evaluation was carried out by thirty panellists using a 7 point hedonic scale from 1 to $7(1=$ dislike extremely, 2 $=$ dislike very much, $3=$ like slightly, $4=$ neither like nor dislike, $6=$ like very much, $7=$ like extremely) (Mamat et al., 2018).

\subsection{Statistical analysis}

All the results obtained from analysis data were analysed using Minitab 18 software and presented in mean \pm standard deviation. The data was collected and analysed using one-way variance (ANOVA) with multiple comparisons and calculation of the significant difference (Shin et al., 2019). 


\section{Results and discussion}

\subsection{Development of Clitoria ternatea leaves pastille}

The $C$. ternatea leaf pastille was developed and several tests carried out to determine its physical characteristics, chemical composition and sensory preference. Table 2 shows that variations in the percentage of $C$. ternatea leaves used may or may not substantially affect the size, thickness, diameter and weight attributes of pastille produced. Although there are some variations in size, weight $(0.70-0.96 \mathrm{~cm})$ and thickness $(0.82-0.97 \mathrm{~cm})$, diameter $(1.40-1.49 \mathrm{~cm})$ and the weight $(2.16-2.20 \mathrm{~g})$. The variety of mass for all the samples may be due to the increasing amount of $C$. ternatea leaves used and the shaping technique before dehydrating the pastille. Silva et al. (2016) observed that the addition of lidocaine and nystatin resulted in pastille with a weight that was significantly different from that of the control pastille. The addition of the cherry pomace extract would probably increase water retention in flours. Similarly to the current study, the increased water retention in flours with the inclusion of $C$. ternatea leaves might contribute to the increase in weight of the pastille. Table 2 illustrates the diameter of the $C$. ternatea leaves and the control pastille. The control pastille has the highest thickness of $1.45 \mathrm{~cm}$ and formulation $\mathrm{E}$ exhibited the lowest thickness $(1.42 \mathrm{~cm})$. The increasing percentage of $C$. ternatea leaves pastille showed a decreasing value in the diameter and thickness of the pastille. Supplementation with C. ternatea leaves resulted in a pastille being produced with significantly greater weight compared to control.

\subsection{Chemical analysis}

Table 3 shows a decreasing pattern of the moisture content was observed, probably due to the decreasing amount of water in the pastille formulations. The control sample $(17.76 \%)$ showed a higher moisture content followed by A (17.47\%), B (16.41\%), D (15.61\%), C (15.06\%) and E (14.74\%). Ergun et al. (2010) quoted that gummies and jellies should have a moisture content of $8-22 \%$ and the C. ternatea leaves pastille of are within this range. The moisture content might affect the sensory acceptance of the product as it is also related to water activity. Barbosa-Cánovas et al. (2008) and Ergun et al. (2010), quoted that moisture content and water activity in confectionery develop the moisture sorption isotherm

Table 2. Dimensions (size and weight) of C. ternatea leaves pastille

\begin{tabular}{|c|c|c|c|c|}
\hline Sample & Picture & Thickness $(\mathrm{cm})$ & Height $(\mathrm{cm})$ & Weight(g) \\
\hline Control & & $0.89 \pm 0.05^{\mathrm{a}}$ & $1.47 \pm 0.05^{\mathrm{a}}$ & $2.09 \pm 0.06^{\mathrm{a}}$ \\
\hline $\begin{array}{l}\text { A } \\
(2.5 \% \text { C. ternatea leaves })\end{array}$ & & $0.96 \pm 0.14^{\mathrm{a}}$ & $1.45 \pm 0.03^{\mathrm{a}}$ & $2.18 \pm 0.14^{\mathrm{a}}$ \\
\hline $\begin{array}{l}\text { B } \\
(5.0 \% \text { C. ternatea leaves })\end{array}$ & & $0.82 \pm 0.06^{\mathrm{a}}$ & $1.46 \pm 0.04^{\mathrm{a}}$ & $2.16 \pm 0.04^{\mathrm{a}}$ \\
\hline $\begin{array}{l}\text { C } \\
(7.5 \% \text { C. ternatea leaves })\end{array}$ & & $0.97 \pm 0.05^{\mathrm{a}}$ & $1.42 \pm 0.05^{\mathrm{a}}$ & $2.20 \pm 0.11^{\mathrm{a}}$ \\
\hline $\begin{array}{l}\text { D } \\
(10.0 \% \text { C. ternatea leaves })\end{array}$ & & $0.86 \pm 0.03^{\mathrm{a}}$ & $1.40 \pm 0.03^{\mathrm{a}}$ & $2.18 \pm 0.00^{\mathrm{a}}$ \\
\hline $\begin{array}{l}\mathrm{E} \\
(12.5 \% \text { C. ternatea leaves })\end{array}$ & & $0.89 \pm 0.04^{\mathrm{a}}$ & $1.49 \pm 0.02^{\mathrm{a}}$ & $2.16 \pm 0.01^{\mathrm{a}}$ \\
\hline
\end{tabular}

Values are expressed as mean \pm standard deviation. Values with the same superscript within the column are not significantly different at $\mathrm{p}>0.05$. 
Table 3. Moisture, ash, fibre, calorie content, total flavonoid content (TFC), total phenolic content (TPC) and DPPH in $C$. ternatea leaves pastille

\begin{tabular}{cccccccc}
\hline Sample & Moisture (\%) & Ash (\%) & Fibre (\%) & Calorie (cal/g) & TFC (ppm) & TPC & DPPH \\
\hline Control & $17.76 \pm 1.39^{\mathrm{a}}$ & $0.52 \pm 1.68^{\mathrm{b}}$ & $1.30 \pm 1.47^{\mathrm{a}}$ & $3.93 \pm 0.40 \mathrm{a}$ & $0.00 \pm 0.07^{\mathrm{c}}$ & - & $0.69 \pm 0.02^{\mathrm{d}}$ \\
A & $17.47 \pm 0.59^{\mathrm{a}}$ & $4.61 \pm 1.47^{\mathrm{ab}}$ & $1.34 \pm 1.47^{\mathrm{a}}$ & $3.96 \pm 0.56^{\mathrm{a}}$ & $0.32 \pm 0.05^{\mathrm{bc}}$ & $10.61 \pm 1.12^{\mathrm{a}}$ & $13.61 \pm 1.56^{\mathrm{c}}$ \\
B & $16.41 \pm 0.14^{\mathrm{a}}$ & $5.93 \pm 0.88^{\mathrm{a}}$ & $1.58 \pm 1.47^{\mathrm{a}}$ & $4.03 \pm 0.88^{\mathrm{a}}$ & $0.56 \pm 0.17^{\mathrm{b}}$ & $15.26 \pm 1.17^{\mathrm{a}}$ & $16.34 \pm 2.13^{\mathrm{c}}$ \\
C & $15.06 \pm 0.58^{\mathrm{ab}}$ & $7.54 \pm 2.27^{\mathrm{a}}$ & $1.62 \pm 1.47^{\mathrm{a}}$ & $4.05 \pm 0.93^{\mathrm{a}}$ & $0.70 \pm 0.07^{\mathrm{b}}$ & $16.89 \pm 2.02^{\mathrm{a}}$ & $21.27 \pm 4.43^{\mathrm{bc}}$ \\
D & $15.61 \pm 0.82^{\mathrm{ab}}$ & $7.53 \pm 1.92^{\mathrm{a}}$ & $1.31 \pm 1.47^{\mathrm{a}}$ & $3.98 \pm 0.71^{\mathrm{a}}$ & $0.65 \pm 0.12^{\mathrm{b}}$ & $21.43 \pm 3.11^{\mathrm{a}}$ & $20.21 \pm 2.56^{\mathrm{bc}}$ \\
E & $14.74 \pm 1.50^{\mathrm{b}}$ & $6.08 \pm 1.40^{\mathrm{a}}$ & $1.12 \pm 1.47^{\mathrm{a}}$ & $4.09 \pm 0.21^{\mathrm{a}}$ & $1.45 \pm 0.01^{\mathrm{a}}$ & $23.32 \pm 0.17^{\mathrm{a}}$ & $22.86 \pm 5.65^{\mathrm{b}}$ \\
$-\alpha$-tocopherol & & & & & & & $63.56 \pm 6.66^{\mathrm{a}}$ \\
BHT & & & & & & & $75.11 \pm 3.98^{\mathrm{a}}$ \\
\hline
\end{tabular}

Values are expressed as mean \pm standard deviation. Values with the same superscript within the column are not significantly different at $\mathrm{p}>0.05$.

A: $2.5 \%$ C. ternatea leaves, B: 5.0\% C. ternatea leaves, C: $7.5 \%$ C. ternatea leaves, D: $10.0 \%$ C. ternatea leaves and E: $12.5 \%$ C. ternatea leaves.

where it is very crucial in determining the shelf life and product's stability.

The results show that there is no significant difference $(p>0.05)$ in the ash content of the samples tested. Sample C and D exhibited higher ash content (7.54 and $7.53 \%$ ) compared to that of the other samples (Table 3). Taha and co-workers (2012) mentioned that the use of gums would result in $0.63 \%$ of ash content while Combretum gum has $4.33 \%$ while Olibanum gum has $1.77 \%$ of ash content. The high value of the ash content in this study is possibly due to the presence of natural ash content in all the ingredients used in producing the $C$. ternatea leaf herbal pastille.

The fibre content sample C (1.62\%) was higher than that of other samples (Table 3). It might be due to the different fibre composition in the flour in the ingredients. This is in concert with the study by Satyanarayana et al. (1982), who quoted fibres from various parts of the coconut tree and suggested that chemical constituents are different in value due to the different parts of the tree.

Sample E shows the highest calorie content (4.09 $\mathrm{cal} / \mathrm{g})$ followed by C $(4.05 \mathrm{cal} / \mathrm{g}), \mathrm{B}(4.03 \mathrm{cal} / \mathrm{g}), \mathrm{D}(3.98$ $\mathrm{cal} / \mathrm{g})$, A $(3.96 \mathrm{cal} / \mathrm{g})$, and control $(3.93 \mathrm{cal} / \mathrm{g})$, respectively (Table 3 ). Studies on bromatological analysis of $C$. ternatea leaf justified that the leaves have the chemical composition that continues to the energy (Deshmukh and Jadhav, 2014).

\subsubsection{Total phenolic content (TPC)}

The total phenolic content (TPC) of the pastilles sample is directly proportional to the volume of $C$. ternatea leaves incorporated in the pastille (Table 3). Sample E (23.32 ppm) exhibited higher TPC value compared to other samples. Nithianantham et al. (2011), claimed that $C$. ternatea leaves contain between 0.43 to $72.82 \mathrm{mg} / \mathrm{g}$. Loss of TPC in C. ternatea leaves is probably due to the degradation of phenolic compounds during storage and through processing such as heating and drying. Tomás-Barberán et al. (2001) stated that phenolic compounds are pertinent to the flavour, appearance and health-promoting properties and some might contribute to aroma. It means that the phenolic compounds are volatile compounds that can be easily vaporised from the substances due to several factors such as light and temperature.

\subsubsection{Total flavonoid content (TFC)}

The-results show that sample E contains significantly the highest $(\mathrm{p}<0.05)$ total flavonoid content (Table 3 ). This was probably due to the higher amount of $C$. ternatea leaves incorporated in the formulation. Furthermore, the control sample contains no flavonoids which reflect the formulation that contains no $C$. ternatea leaves. Both flavonoid and phenolic compound play a role as the antioxidant compound. Liew et al. (2020) found that the phenolic and flavonoid content in spices could prevent oxidative stress-related disease and they also claimed that antioxidant activity is mainly phenolic compounds and flavonoids.

\subsubsection{Antioxidant capacity using (2),(2)-diphenyl-2- picrylhydrazyl (DPPH) radical scavenging assay}

Table 3 also shows a gradual increased pattern in control to sample E which might be influenced by the presence of $C$. ternatea leaves. Sample E exhibited significantly $(p<0.05)$ higher antioxidative activity than that of other samples except for sample C and D. The amount $C$. ternatea leaves in the pastille samples might be the main reasons for the results. Lim (2014) stated that the antioxidant activity of $C$. ternatea methanol leaf extract was $67.85 \%$ at a concentration of $1 \mathrm{mg} / \mathrm{mL}$. However, pastilles of $C$. ternatea leaves exhibited lower inhibition, probably due to the processing and storage which involves fluctuating temperature and being kept 
for some period thus, the phenolic compound has degraded. Rai (2010) suggested that flavonoid compounds in $C$. ternatea may act as antioxidant principally and Chauhan et al. (2012) stated that leaves of $C$. ternatea contain 3 monoglucoside, 3-rutinoside, 3neohisperidoside, 3-o-rhamnosyl Glycoside, kaempferol3-o-rhamnosyl, aparajitin, beta-sitosterol, and essential oil.

\subsection{Physical analysis}

\subsection{1 $\mathrm{pH}$ and water activity}

If the $\mathrm{pH}$ value is lower than 3.00, time for deposition of the mixture into the mould may be short as pre-gelation may occur right after the acid being added (Herbstreith and Fox, 2004). The $\mathrm{pH}$ value of 3.2-3.6 in the pastille samples was adequate in producing the pastilles for a firm and elastic texture. The water activity $\left(a_{w}\right)$ in all the samples including the control shows no significant difference $(\mathrm{p}>0.05)$, ranging from 0.73 (sample B) to 0.71 (control). Gums, jellies like pastille should have 0.50-0.75 $\mathrm{a}_{\mathrm{w}}$ (Fontana, 1995) while Ergun et al. (2010) stated that the $\left(\mathrm{a}_{\mathrm{w}}\right)$ that should be in gummies and jellies product is between $0.50-0.75$. This means that the pastilles produced from leaves of $C$. ternatea were within the range and managed to prevent most spoilage microorganisms from surviving. Water activity could be used as a predictor of shelf-life stability, as we could predict the growth of microorganisms that are bacteria, yeasts and moulds that could be pathogenic and harmful to be consumed.

\subsubsection{Syneresis analysis}

Table 4 also shows that there were no significant differences within the $C$. ternatea leaf pastille samples with syneresis found in control (95.01\%) followed by, E (94.35\%), D (94.12\%), B (92.88\%), C (92.36\%), and A $(92.28 \%)$. Syneresis indicates the phase-separation of the serum, mostly at the top of the product, and presumably caused by a contraction of the gel-matrix combined with sedimentation during storage. The possible reason for syneresis to occur are gelatine and starch behaviour during storage (Ruth et al., 2004). Gaston et al. (2007) reported that starch and gelatine syneresis also being attributed by the addition of both ingredients in yoghurt, which gelatine is more effective in preventing syneresis. Syneresis of $C$. ternatea leaf pastilles was probably due to the hygroscopic properties of the sample, which tends to absorb surrounding water. Inadequate amount of gelatine in the sample formulations could increase the tendency of syneresis to occur as well (Kunitz, 1928: El Bouchikhi et al., 2019).

\subsection{Texture profile analysis}

Texture profile analysis is important in food processing because physical testing could tell us a lot about their tactile properties: firmness, fracture-ability, resilience and other parameters. The hardest sample (hardness value) was the control $(2641.70 \mathrm{~g})$, followed by samples E $(2414.58 \mathrm{~N})$, D $(2091.84 \mathrm{~N})$, A $(2009.09$ $\mathrm{N}), \mathrm{C}(1989.58 \mathrm{~N})$, and $\mathrm{B}(1599.33 \mathrm{~N})$, respectively (Table 5). In commercial gelatine gummies, the hardness of the gelatine gummy is $897.88 \mathrm{~N}$ (Normah and Muhammad Fahmi, 2015). The difference in the values could be attributed to the usage of gelatine and gum arabic as the gelling agent in the $C$. ternatea leaf pastille but only gelatine was used in commercial pastilles.

In the adhesiveness profile, there are no significant differences observed, with values ranging from $-1.34 \mathrm{~N}$ (sample E) to $-6.99 \mathrm{~N}$ (sample D). However, the cohesiveness value of the samples shows a somewhat significant difference in sample D and E compared to other samples. The cohesive values might be influenced by the hygroscopicity that took place during the storage period (Normah and Muhammad Fahmi 2015). Adhesiveness could be defined as the work necessary to overcome the adhesive forces between the surface of the sample and the surface of other materials with which the sample comes into contact with teeth and mouth's wall (Paula and Conti-Silva, 2014) while cohesiveness means the mechanical textural attribute relating to the degree to which a food can be deformed before it breaks (Di Monaco et al., 2008).

Table 4. Total soluble solid, $\mathrm{pH}$ and water activity of pastille produced from leaves of C. ternatea

\begin{tabular}{ccccc}
\hline Sample & Total Soluble Solid $\left({ }^{\circ}\right.$ Brix $)$ & $\mathrm{pH}$ value & Water activity $\left(\mathrm{a}_{\mathrm{w}}\right)$ & Syneresis $(\%)$ \\
\hline Control & $72.95 \pm 1.75^{\mathrm{a}}$ & $3.16 \pm 0.08^{\mathrm{a}}$ & $0.71 \pm 0.012^{\mathrm{a}}$ & $95.01 \pm 0.80^{\mathrm{a}}$ \\
$\mathrm{A}$ & $71.60 \pm 3.20^{\mathrm{a}}$ & $3.15 \pm 0.12^{\mathrm{a}}$ & $0.72 \pm 0.010^{\mathrm{a}}$ & $92.28 \pm 0.44^{\mathrm{a}}$ \\
$\mathrm{B}$ & $72.45 \pm 0.45^{\mathrm{a}}$ & $3.12 \pm 0.00^{\mathrm{a}}$ & $0.73 \pm 0.009^{\mathrm{a}}$ & $92.88 \pm 0.62^{\mathrm{a}}$ \\
$\mathrm{C}$ & $73.80 \pm 2.00^{\mathrm{a}}$ & $3.14 \pm 0.01^{\mathrm{a}}$ & $0.72 \pm 0.004^{\mathrm{a}}$ & $92.36 \pm 0.59^{\mathrm{a}}$ \\
$\mathrm{D}$ & $74.20 \pm 2.50^{\mathrm{a}}$ & $3.06 \pm 0.10^{\mathrm{a}}$ & $0.72 \pm 0.003^{\mathrm{a}}$ & $94.12 \pm 0.31^{\mathrm{a}}$ \\
E & $69.80 \pm 1.20^{\mathrm{a}}$ & $3.09 \pm 0.06^{\mathrm{a}}$ & $0.72 \pm 0.003^{\mathrm{a}}$ & $94.35 \pm 0.58^{\mathrm{a}}$ \\
\hline
\end{tabular}

Values are expressed as mean \pm standard deviation. Values with the same superscript within the column are not significantly different at $\mathrm{p}>0.05$.

A: $2.5 \%$ C. ternatea leaves, B: $5.0 \%$ C. ternatea leaves, C: $7.5 \%$ C. ternatea leaves, D: $10.0 \%$ C. ternatea leaves and E: $12.5 \%$ C. ternatea leaves. 
Table 5. Texture profile analysis of $C$. ternatea leaves pastilles

\begin{tabular}{lcccccc}
\hline & Control & A & B & C & D & E \\
\hline Hardness (g) & $2641.70 \pm 529.57^{\mathrm{a}}$ & $2009.09 \pm 92.51^{\mathrm{a}}$ & $1599.33 \pm 122.34^{\mathrm{a}}$ & $1989.58 \pm 57.17^{\mathrm{a}}$ & $2091.84 \pm 190.92^{\mathrm{a}}$ & $2414.58 \pm 800.02^{\mathrm{a}}$ \\
Adhesiveness & $-5.03 \pm 4.94^{\mathrm{a}}$ & $-6.96 \pm 6.09^{\mathrm{a}}$ & $-5.32 \pm 4.55^{\mathrm{a}}$ & $-5.69 \pm 4.38^{\mathrm{a}}$ & $-6.99 \pm 4.49^{\mathrm{a}}$ & $-1.34 \pm 0.43^{\mathrm{a}}$ \\
Springiness & $0.87 \pm 0.12^{\mathrm{a}}$ & $0.79 \pm 0.02^{\mathrm{a}}$ & $0.71 \pm 0.04^{\mathrm{a}}$ & $0.82 \pm 0.07^{\mathrm{a}}$ & $0.65 \pm 0.09^{\mathrm{a}}$ & $0.67 \pm 0.06^{\mathrm{a}}$ \\
Cohesiveness & $0.87 \pm 0.05^{\mathrm{a}}$ & $0.76 \pm 0.05^{\mathrm{a}}$ & $0.70 \pm 0.02^{\mathrm{ab}}$ & $0.75 \pm 0.04^{\mathrm{a}}$ & $0.56 \pm 0.00^{\mathrm{b}}$ & $0.61 \pm 0.01^{\mathrm{b}}$ \\
Gumminess & $2338.75 \pm 600.06^{\mathrm{a}}$ & $1543.83 \pm 166.00^{\mathrm{a}}$ & $1115.42 \pm 60.84^{\mathrm{a}}$ & $1507.30 \pm 121.88^{\mathrm{a}}$ & $1160.73 \pm 98.33^{\mathrm{a}}$ & $1563.57 \pm 447.30^{\mathrm{a}}$ \\
Chewiness & $2089.71 \pm 790.82^{\mathrm{a}}$ & $1268.03 \pm 44.14^{\mathrm{a}}$ & $783.47 \pm 1.91^{\mathrm{a}}$ & $1188.09 \pm 32.05^{\mathrm{a}}$ & $750.35 \pm 39.84^{\mathrm{a}}$ & $967.62 \pm 253.90^{\mathrm{a}}$ \\
\hline
\end{tabular}

Values are expressed as mean \pm standard deviation. Values with the same superscript within the column are not significantly different at $\mathrm{p}>0.05$.

A: $2.5 \%$ C. ternatea leaves, B: $5.0 \%$ C. ternatea leaves, C: $7.5 \%$ C. ternatea leaves, D: $10.0 \%$ C. ternatea leaves and E: $12.5 \%$ C. ternatea leaves.

Springiness values (ability to regain its original shape) of the samples ranges from $0.87 \mathrm{~N}$ (control) 0.79 $\mathrm{N}$ (sample A), $0.71 \mathrm{~N}$ (sample B) $0.82 \mathrm{~N}$ (sample C) 0.67 $\mathrm{N}$ (sample E) and $0.65 \mathrm{~N}$ (sample D). Jelly candy-like products should range between $0.40 \mathrm{~N}$ to $0.95 \mathrm{~N}$ (Habilla and Cheng, 2015). It is possibly because of the same ingredients being used in jelly production such as glucose syrup and citric acid. In addition, it also might be due to the basic function of gum which is as a thickener and stabilizer in confectionery products.

All of the samples show no significant difference in gumminess profile to the control $(2338.75 \mathrm{~N})$ followed by sample E (1563 N), sample A (1543.83 N), sample C $(1507.30 \mathrm{~N})$, sample $\mathrm{D}(1160.73 \mathrm{~N})$ and sample $\mathrm{B}$ (1115.42 N). Habilla and Cheng (2015) showed the sample without gum was gummier than the sample with gum addition. It probably could be said that the addition of ingredients in the formulation will reduce the gumminess texture in the product.

The quantitative chewiness value of the pastille in this study (ranging from $783.03 \mathrm{~N}$ to $2089.71 \mathrm{~N}$ ) was higher compared to the commercial gummy candy with gelatine $(872.83 \mathrm{~N})$ (Milani and Maleki, 2012). This is probably due to the Gum Arabic presence in the pastille as Milani and Maleki (2012) quoted that the higher the gum Arabic content, the softer and the chewier the candy.

\subsection{Colour profile}

The lightness ( $\mathrm{L}^{*}$ value) consistently decreased (became darker) when more $C$. ternatea leaves were used in the pastilles (Table 6). This is probably due to the pigment breakdown during storage which results in a dramatically changed colour during storage (Sui et al., 2015). The $a^{*}$ value indicates the green-red value, (the more negative value will contribute to green colour while a positive value will refer to the reddish colour). There were somewhat significant differences between control and sample A, B, C and E. The highest positive value was represented by the control $(0.73)$ and the highest negative value was represented by sample A. The data also show that there are no significant differences between the value $b^{*}$ (blue-yellow colour) with the most positive values ranging from 18.87 to 9.28 , which means that they tend to be in yellow. Gouveia et al. (2008) quoted that this phenomenon was the result of correlation activity of $D$. vilkianum and $S$. maxima. When the $D$. vilkianum shows higher activity compared to $S$. maxima, presenting a higher negative $a^{*}$ which is a tendency to give a green hue and positive $b^{*}$ with a tendency to yellow hue, and both of them are closer to zero value, an unattractive tonality is reflected which produces a yellow -brownish colour based on the chart of CIE Hunterlab.

\subsection{Sensory evaluation}

The sensory preference (appearance, colour, odour, texture, taste and overall acceptance) results of pastilles incorporated with $2.5 \%, 5.0 \%, 7.5 \%, 10 \%$, and $12.5 \%$ of C. ternatea leaves are shown in Table 7. The appearance of sample $\mathrm{C}$ was significantly preferred by the panellists which are probably due to the desirable colour variation that was affected through heating and caramelization. This is probably due to the brighter colours of the sample as the control exhibits a colour with a value of $\mathrm{L}^{*}$ higher than others observed by the CIE Lab colourimeter. Jaime and Monteiro (2005) quoted that some specific colours, such as green vegetables, as well as darker colour which is not preferred by panels, are less accepted by the general population. The colour evaluation also showed a significant difference with the value of $(p<0.05)$ between samples $\mathrm{C}, \mathrm{D}$ and $\mathrm{E}$ and the control. The appearance results could be linked with the colour acceptance judged by the panels as based on the results of colour, panels prefer a brighter sample colour. The control sample received the highest preference for the odour attributes by the panellists. It might be possible that panels do not like the acidic odour contributed by citric acid and for all the samples of A, B, C, D, and E, the combination of acidic odour with the leafy odour might not be tolerated by most panels. Similarly, Normah and Muhammad Fahmi (2015) reported that panels prefer the odour from 
Table 6. Colour profile analysis of herbal pastilles affected by the inclusion of C. ternatea (L.) leaves

\begin{tabular}{cccc}
\hline Sample & $\mathrm{L}^{*}$ & $\mathrm{a}^{*}$ & $\mathrm{~b}^{*}$ \\
\hline Control & $66.25 \pm 2.22^{\mathrm{a}}$ & $0.73 \pm 0.51^{\mathrm{a}}$ & $10.96 \pm 0.70^{\mathrm{a}}$ \\
A & $62.75 \pm 4.69^{\mathrm{a}}$ & $-3.62 \pm 0.40^{\mathrm{b}}$ & $17.04 \pm 0.09^{\mathrm{a}}$ \\
B & $58.78 \pm 6.78^{\mathrm{a}}$ & $-2.55 \pm 0.14^{\mathrm{b}}$ & $18.87 \pm 2.90^{\mathrm{a}}$ \\
C & $57.16 \pm 10.90^{\mathrm{a}}$ & $-1.81 \pm 0.66^{\mathrm{b}}$ & $14.90 \pm 1.14^{\mathrm{a}}$ \\
D & $47.97 \pm 13.56^{\mathrm{a}}$ & $-0.76 \pm 0.08^{\mathrm{ab}}$ & $9.28 \pm 2.73^{\mathrm{a}}$ \\
E & $50.46 \pm 7.90^{\mathrm{a}}$ & $-2.65 \pm 0.31^{\mathrm{b}}$ & $16.25 \pm 2.54^{\mathrm{a}}$ \\
\hline
\end{tabular}

Values are expressed as mean \pm standard deviation. Values with the same superscript within the column are not significantly different at $\mathrm{p}>0.05$.

A: $2.5 \%$ C. ternatea leaves, B: $5.0 \%$ C. ternatea leaves, C: $7.5 \%$ C. ternatea leaves, D: $10.0 \%$ C. ternatea leaves and E: $12.5 \%$ C. ternatea leaves.

Table 7. Sensory preference obtained from sensory evaluation of C. ternatea leaves pastille

\begin{tabular}{lcccccc}
\hline & Control & $\mathrm{A}$ & $\mathrm{B}$ & $\mathrm{C}$ & $\mathrm{D}$ & $\mathrm{E}$ \\
\hline Appearance & $5.87 \pm 0.92^{\mathrm{c}}$ & $4.97 \pm 1.02^{\mathrm{ab}}$ & $4.60 \pm 1.20^{\mathrm{b}}$ & $5.03 \pm 1.25^{\mathrm{ab}}$ & $3.23 \pm 1.38^{\mathrm{a}}$ & $4.23 \pm 1.31^{\mathrm{b}}$ \\
Colour & $5.40 \pm 1.20^{\mathrm{a}}$ & $5.10 \pm 1.22^{\mathrm{ab}}$ & $4.90 \pm 1.04^{\mathrm{ab}}$ & $4.40 \pm 1.28^{\mathrm{b}}$ & $3.43 \pm 1.65^{\mathrm{b}}$ & $4.13 \pm 1.18^{\mathrm{b}}$ \\
Odour & $4.77 \pm 1.15^{\mathrm{a}}$ & $4.57 \pm 1.15^{\mathrm{ab}}$ & $4.23 \pm 0.96^{\mathrm{ab}}$ & $4.40 \pm 1.14^{\mathrm{ab}}$ & $3.53 \pm 1.15^{\mathrm{b}}$ & $3.87 \pm 1.12^{\mathrm{b}}$ \\
Texture & $5.17 \pm 1.44^{\mathrm{a}}$ & $4.40 \pm 1.54^{\mathrm{ab}}$ & $3.70 \pm 1.42^{\mathrm{bc}}$ & $5.30 \pm 1.04^{\mathrm{a}}$ & $2.73 \pm 1.67^{\mathrm{c}}$ & $4.00 \pm 1.69^{\mathrm{b}}$ \\
Taste & $4.77 \pm 1.26^{\mathrm{a}}$ & $4.57 \pm 1.61^{\mathrm{ab}}$ & $3.77 \pm 1.31^{\mathrm{ab}}$ & $4.47 \pm 1.52^{\mathrm{ab}}$ & $3.50 \pm 1.86^{\mathrm{b}}$ & $3.73 \pm 1.63^{\mathrm{ab}}$ \\
Overall Acceptance & $5.03 \pm 1.25^{\mathrm{a}}$ & $4.50 \pm 1.28^{\mathrm{ab}}$ & $3.93 \pm 1.21^{\mathrm{b}}$ & $4.57 \pm 1.28^{\mathrm{ab}}$ & $3.13 \pm 1.54^{\mathrm{c}}$ & $3.80 \pm 1.49^{\mathrm{bc}}$ \\
\hline
\end{tabular}

Values are expressed as mean \pm standard deviation. Values with the same superscript within the column are not significantly different at $\mathrm{p}>0.05$.

A: $2.5 \%$ C. ternatea leaves, B: $5.0 \%$ C. ternatea leaves, C: $7.5 \%$ C. ternatea leaves, D: $10.0 \%$ C. ternatea leaves and E: $12.5 \%$ C. ternatea leaves.

commercial gelatine, as the gelatine from the sutchi catfish probably released a fishy odour. Texture preference tests showed that sample $\mathrm{C}$ was preferred while sample $\mathrm{D}$ was the least preferred. This could be due to the high adhesiveness which made the panel uncomfortable as the pastille is sticky in the mouth and that probably related to the cohesiveness of the sample.

This study also showed that the degree of preference for $C$. ternatea leaf pastilles decreased as the hardness increased. The control sample has the highest taste preference followed by sample A, C, B, E and D. The data suggests that panels did not like the leafy, sour and bitter taste of the samples. The bitter taste can be caused by the phenolic compounds present in the sample (Tomás-Barberán and Espin, 2001). In addition, sour taste from citric acid might not be accepted by some people as it rapidly triggers the acidic taste compared to other acids (Humayun et al., 2014). The panellists prefer sample A, B and E as these samples contain moderate amounts of $C$. ternatea leaves.

\section{Conclusion}

The study demonstrates the possible use of $C$. ternatea leaves as herbal pastille, which has affected the physicochemical and organoleptic properties of the final products. The study indicates the potential use of $C$. ternatea leaves as a herbal pastille which has major impacts on the physicochemical and organoleptic properties of the final products. The newly produced formulation of the $C$. ternatea herbal pastille had suitable properties for oral administration. Sample A has mostly been preferred by the panellist. Unanimously, the panellists accepted their pastille characteristics based on the sensory analysis. This product is suitable for everyone's consumption as it offers beneficial health compounds such as antioxidants. This study has shown that $C$. ternatea leaves can be used in the production of herbal pastilles, offering a greater variety of uses in the food industry.

\section{Conflict of interest}

The authors declare that there is no conflict of interest in conducting this study.

\section{Acknowledgments}

The researchers are grateful to the Faculty of Fisheries and Food Sciences UMT for the facilities and financial resources for this work.

\section{References}

AOAC. (2007). Official Methods of Analysis of AOAC International. AOAC Official Method 990.26. 17th ed. Gaithersburg, MD. USA: AOAC International.

Azuan, A.A., Mohd Zin, Z., Hasmadi, M., Rusli, N.D. and Zainol, M.K. (2020). Physicochemical, 
antioxidant and sensory characteristics of cookies supplemented with different levels of spent coffee ground extract. Food Research, 4(4), 1181 - 1190. https://doi.org/10.26656/fr.2017.4(4).058

Barbosa-Cánovas, G.V., Fontana, A.J., Schmidt, S.J. and Labuza, T.P. (Eds.) (2008). Water activity in foods: Fundamentals and applications. United Kingdom: Blackwell Publishing Ltd. https:// doi.org/10.1002/9780470376454

Chauhan, N., Rajvaidhya, S. and Dudey, B.K. (2012). Pharmacognostical, phytochemical and pharmacological review on Clitoria ternatea for antiasthmatic activity. International Journal of Pharmaceutical and Sciences and Researches, 3, 398-404.

Silva, F.C., Marto, J.M., Salgado, A., Machado, P., Silva, A.N., and Almeida, A.J. (2016). Nystatin and lidocaine pastilles for the local treatment of oral mucositis. Pharmaceutical Development and Technology, 22(2), 266-274. https:// doi.org/10.1080/10837450.2016.1221424.

DeFilipps, R.A. and Krupnick, G.A. (2018). The medicinal plants of Myanmar. PhytoKeys, 102, 1341. http://doi.org/10.3897/phytokeys.102.24380.

Di Monaco, R., Cavella, S. and Masi, P. (2008). Predicting sensory cohesiveness, hardness and springiness of solid foods from instrumental measurements. Journal of Texture Studies, 39(2), 129-149. http://doi.org/10.1111/j.17454603.2008.00134.x

El Bouchikhi, S., Pagès, P., El Alaoui, Y., Ibrahimi, A. and Bensouda, Y. (2019). Syneresis investigations of lacto-fermented sodium caseinate in a mixed model system. BMC Biotechnology, 19, 57. http:// doi.org/10.1186/s12896-019-0539-1

Ergun, R., Lietha, R. and Hartel, R.W. (2010). Moisture and shelf life in sugar confections. Critical Reviews in Food Science and Nutrition, 50(2), 162192. http://doi.org/10.1080/10408390802248833

Habilla, C. and Cheng, L.H. (2015). Quality of jelly candy made of acid-thinned starch added with different non- starch polysaccharides. Journal of Food Research and Technology, 3(1), 14-22.

Herbstreith and Fox. (2004). Confectionery Gum and Jelly Products. p. 1-31. Nuremberg, Germany: Herbstreith and Fox

Hui, C.K., Majid, N.I., Mohd Zainol, M.K., Mohamad, H. and Mohd Zin, Z. (2018). Preliminary phytochemical screening and effect of hot water extraction conditions on phenolic contents and antioxidant capacities of Morinda citrifolia leaf. Malaysian Applied Biology, 47(4), 13-24.
Humayun, A., Gautam, C.K., Madhav, M., Sourav, S. and Ramalingam, C. (2014). Effect of citric and malic acid on shelf life and sensory characteristics of orange juice. International Journal of Pharmacy and Pharmaceutical Sciences, 6(2), 117119.

Jaime, P.C. and Monteiro, C.A. (2005). Fruit and vegetable intake by Brazilian adults. Cadernos de Saúde Pública, 21(Suppl 1), S19-S24. http:// doi.org/10.1590/s0102-311x2005000700003

Kaisoon, O., Siriamornpun, S., Weerapreeyakul, N. and Meeso, N. (2011). Phenolic compounds and antioxidant activities of edible flowers from Thailand. Journal of Functional Foods, 3(2), 88-99. https://doi.org/10.1016/j.jff.2011.03.002.

Kunitz, M. (1928). Syneresis and swelling of gelatine. The Journal of General Physiology, 12(2), 289312. http://doi.org/10.1085/jgp.12.2.289

Liew, S.Y., Mohd Zin, Z., Mohd Maidin, N.M., Mamat, H. and Zainol, M.K. (2020). Effect of the different encapsulation methods on the physicochemical and biological properties of Clitoria ternatea flowers microencapsulated in gelatine. Food Research, 4(4), 1098-1108. http://doi.org/10.26656/fr.2017.4(4).033

Lijon, M.B., Meghla, N.S., Jahedi, E., Rahman, M.A. and Hossain, I. (2017). Phytochemistry and pharmacological activities of Clitoria ternatea. International Journal of Natural and Social Sciences, 4(1), 1-10

Lim T.K. (Ed.) (2014) Clitoria ternatea. In Edible Medicinal and Non-Medicinal Plants. Dordrecht: Springer. Retrieved from https://doi.org/10.1007/978 -94-007-7395-0_62

Lubbers, S. and Guichard, E. (2003). The effect of sugars and pectin on flavour release from a fruit pastille model system. Food Chemistry, 81(2), 269-273. https://doi.org/10.1016/S0308-8146(02)00422-3

Malik, N.H., Zin, Z.M., Razak, S.B.A., Ibrahim, K. and Zainol, M.K. (2017). Antioxidative activities and flavonoids contents in leaves of selected mangrove species in Setiu wetlands extracted using different solvents. Journal of Sustainability Science and Management, 3, 14-22

Mamat, H., Akanda, J.M.H., Zainol, M.K. and Yu, A.I. (2018). The influence of seaweed composite flour on the physicochemical properties of muffin. Journal of Aquatic Food Product Technology, 27(5), 635-642, https:// doi.org/10.1080/10498850.2018.1468841.

Milani, J. and Maleki, G. (2012). Hydrocolloids in food industry. In Valdez, B. (Ed.) Food Industrial Processes. Methods and Equipment. InTech Open EBook. https://doi.org/10.5772/32358 
Mukherjee, P.K., Kumar, V., Kumar, N.S. and Heinrich, M. (2008). The Ayurvedic medicine Clitoria ternatea-from traditional use to scientific assessment. Journal of Ethnopharmacology, 120(3), 291-301. http://doi.org/10.1016/j.jep.2008.09.009

Neda, G.D., Rabeta, M.S. and Ong, M.T. (2013). Chemical composition and anti- proliferative properties of flowers of Clitoria ternatea. International Food Research Journal, 20(3), 12291234.

Nithianantham, K., Shyamala, M., Chen, Y., Latha, L.Y., Jothy, S. L. and Sasidharan, S. (2011). Hepatoprotective potential of Clitoria ternatea leaf extract against paracetamol induced damage in mice. Molecules, 16(12), 10134-10145. http:// doi.org/10.3390/molecules 161210134

Normah, I. and Muhammad Fahmi, I. (2015). Physicochemical characteristics of gummy added with sutchi catfish (Pangasius hypophthalmus) gelatinInternational. Food Research Journal, 22(3), 1059-1066.

Paula, A.M. and Conti-Silva, A.C. (2014). Texture profile and correlation between sensory and instrumental analyses on extruded snacks. Journal of Food Engineering, 121, 9-14. http://doi.org/10.1016/ j.jfoodeng.2013.08.007

Rai, K.S. (2010). Neurogenic potential of Clitoria ternatea aqueous root extract-a basis for enhancing learning and memory. World Academy of Science, Engineering and Technology, 46, 508-513.

Satyanarayana, K.G., Pillai, C.K.S., Sukumaran, K., Pillai, S.G.K., Rohatgi, P.K. and Vijayan, K. (1982). Structure property studies of fibres from various parts of the coconut tree. Journal of Materials Science, 17(8), 2453-2462. http:// doi.org/10.1007/bf00543759

Shin, N.G.K., Zin, Z.M., Maidin, N.M., Abdullah, M.A.A. and Zainol, M.K. (2019). Effect of drying temperatures on antioxidant properties of Napier grass (Pennisetum purpureum). Asian Journal of Agriculture and Biology, 7(1), 39-48

Shukri, M., Mohd Zin, Z., Zainol, M.K., Said, S., Ngah, A. and Abdullah, S.S. (2017). Integrating computerbased method into dietary intervention in children at setiu wetland: A pilot study. Journal of Sustainability Science and Management, 12(2), 176182.

Subramaniam, P. (2011). The stability and shelf life of confectionery products. In Kilcast, D. and Subramanian, P. (Eds.) Food and Beverage Stability and Shelf Life. USA: Woodhead Publishing Limited. http://doi.org/10.1533/9780857092540.3.716
Taha, K.K., Elmahi, R.H., Hassan, E.A., Ahmed, S.E. and Shyoub, M.H. (2012). Analytical study on three types of gum from Sudan. Journal of Forest Products and Industries, 1(1), 11-16

Tomás-Barberán, F.A., Gil, M.I., Cremin, P., Waterhouse, A.L., Hess-Pierce, B. and Kader, A.A. (2001). HPLC-DAD-ESIMS analysis of phenolic compounds in nectarines, peaches, and plums. Journal of Agricultural and Food Chemistry, 49(10), 4748-4760. http://doi.org/10.1021/jf0104681

Wetwitayaklung, P., Phaechamud, T., Limmatvapirat, C. and Keokitichai, S. (2008). The study of antioxidant activities of edible flower extracts. Acta Horticulturae, 786, 185-192. http:// doi.org/10.17660/actahortic.2008.786.20

Zainol, M.K., Wong, K.Y., Mohd Zin, Z., Kamarudin, K.S., Danish-Daniel, A., Ng. K.S. and Mamat, H. (2018). Effect of ethanol in ultrasonic assisted extraction technique on antioxidative properties of passion fruit (Passiflora edulis) leaves. Malaysian Applied Biology Journal, 47(6), 19-27.

Zainol, M.K., Che-Esa, N.S., Azlin-Hasim, S., Zamri, A.I., Mohd Zin, Z. and Abdul Majid, H.A. (2020). The ramification of arabic gum and gelatine incorporation on the physicochemical properties of belimbing buluh (Averhoa belimbi) fruits pastilles. Food Research, 4(2), 532-538. http:// doi.org/10.26656/fr.2017.4(2).319

Zeng, J., Gao, H. and Li, G. (2014). Functional properties of wheat starch with different particle size distribution. Journal of the Science of Food and Agriculture, 94(1), 57-62. http://doi.org/10.1002/ jsfa.6186

Zhang, L., Sun, D.-W. and Zhang, Z. (2015). Methods for measuring water activity (aw) of foods and its applications to moisture sorption isotherm studies. Critical Reviews in Food Science and Nutrition, 57 (5), 1052-1058. http:// doi.org/10.1080/10408398.2015.1108282 